Government strategies for supporting the adult worker model in European countries: Mixed implications for defamilisation

(Paper accepted by International Journal of Sociology and Social Policy for publication)

Sam Wai Kam YU ${ }^{1}$

Iris Po Yee $\mathrm{LO}^{2}$

Ruby Chui Man CHAU ${ }^{3}$

\footnotetext{
${ }^{1}$ Department of Social Work, Hong Kong Baptist University, Kowloon Tong, Hong Kong; E-mail: samyu@hkbu.edu.hk

${ }^{2}$ Department of Sociology, The University of Oxford, $42-43$ Park End Street, Oxford, OX1 1JD, UK; E-mail: iris.lo@sociology.ox.ac.uk

${ }^{3}$ School of Sociology and Social Policy, The University of Nottingham, Nottingham, NG7 2RD, UK; E-mail: ruby.chau@nottingham.ac.uk
} 


\title{
GOVERNMENT STRATEGIES FOR SUPPORTING THE ADULT WORKER MODEL IN EUROPEAN COUNTRIES: MIXED IMPLICATIONS FOR DEFAMILISATION
}

\begin{abstract}
Purpose - This article explores the link between defamilisation studies and studies of the adult worker model and discusses the mixed implications that government strategies for supporting the adult worker model have for defamilisation. The adult worker model emphasizes that all adult men and women ought to engage in formal employment; defamilisation studies stress the importance of enhancing women's chances of choosing (not) to perform important family roles such as the receiver of financial support and the care provider.

Design/methodology/approach - Two new strategies ('condition building' and 'rewarding/penalizing') for promoting the adult worker model are identified based on literature review; their empirical significance is explored through an examination of comparative data concerning early childhood education and care policies (ECEC) and reforms in pension age in fourteen countries.

Findings - The evidence shows that promoting the adult worker model does not necessarily benefit all women. While the fourteen countries provide ECEC to varying extents, the increase in pension age in most countries shows that governments adopt a 'rewarding/penalizing' strategy for promoting the adult worker model by allocating major welfare based on people's labour force participation. These pension reforms may generate a negative impact on women's chances of attaining financial autonomy.

Originality/value - This study presents two new strategies for promoting the adult worker model and shows the empirical significance of these strategies based on comparative data. It also highlights the importance of searching for alternative concepts, namely economic defamilisation, for guiding pension reforms.
\end{abstract}

Keywords: Adult worker model, defamilisation, pension, family policy

Paper type: Research paper

\section{INTRODUCTION}

This article is concerned with the link between the studies of defamilisation and the studies of the adult worker model. Both types of the studies stress the importance of searching for diverse ways of organising adult life, which serve as alternatives to the practices endorsed by the malebreadwinner model. The male-breadwinner model emphasizes that men should earn financial resources by participating in the work economy, whereas women should take up most of care responsibilities in the family and financially depend on male family members (Lewis and Giullari, 2005). In other words, women are expected to play the role of the care provider and the receiver of financial support in the family. The defamilisation studies raise concerns about women's involuntary participation in unwanted family relationships in society dominated by the male-breadwinner model. Therefore, some of these studies stress the importance of 
exploring ways to provide women with the opportunities to choose to perform or not to perform the roles of the care provider and the receiver of financial support in the family (Bambra, 2007; Kroger, 2011). The studies of the adult worker model are commonly seen to provide challenges to the male-breadwinner model. The adult worker model suggests that both men and women should spend most of their adult life in the work economy (Annesley, 2007). The government is expected to actively develop strategies to motivate women to join the labour force (Lewis and Giullari, 2005; Daly, 2011).

This article has three objectives. The first is to present two strategies that can be used by the government to uphold the adult worker model - the 'condition building' and the 'rewarding/penalizing'. The second is to show that the implementation of these two strategies can have mixed effects on women's chances of choosing to perform such roles as the receiver of financial support and the provider of family care. The third is to demonstrate the empirical significance of these strategies, using comparative data concerning early childhood education and care policies and reforms in pension age. By meeting these three objectives, this article makes contributions to the adult worker model and the defamilisation literature in two ways. Firstly, no studies have examined these two strategies before. Secondly, the discussion of these strategies draws our attention to the possibility that the government's attempt to promote the adult worker model can have mixed impact on women's chances of choosing not to take part in unwanted family relationships. This article starts by discussing the concepts of defamilisation and the adult worker model. It then discusses the comparative data concerning early childhood education and care policies and reforms in pension age. We conclude by highlighting the lessons learnt from the discussion of the comparative data.

\section{DEFAMILISATION}

Different defamilisation studies have different foci (Esping-Andersen, 1999; Israel and Spannagel, 2018; Korpi, 2000; Leitner, 2003; Lister, 1994; Lohmann and Zagel, 2016; McLaughlin and Glendinning, 1994; Saxonberg, 2013). Bambra (2007) has identified two types of defamilisaton studies - stressing the freedom of women and stressing the freedom of the family. The first type of defamilisation studies emphasizes the importance of creating favourable conditions for women to choose the ways of whether and how to take part in family relationships. These studies focus on searching for ways to assist women in seeking financial autonomy in the family (Bambra, 2007; Kroger, 2011; Lister, 1997). In discussing the roles of the welfare regimes in promoting defamilisation, Lister (1994, p.37) shares this view:

'Welfare regimes might then also be characterized according to the degree to which individual adults can uphold a socially acceptable standard of living, independently of family relationships, either through paid work or through the social security system'.

These ideas receive support from other analysts. In studying defamilisation, Taylor-Gooby (1996) focuses on how the welfare state supports women to survive as independent workers and decreases economic importance of the family in women's lives. Bambra (2007) stresses that defamilisation studies should be concerned with the extent to which women can thrive as independent workers and decrease the role of the family in their personal finances. A similar 
view is raised by Kroger (2011, p. 426): 'women need support from social policy to opt out of family and opt to work'.

The second type of defamilisation studies focuses on the family rather than individuals (Leitner, 2003; Esping-Andersen, 1999). These studies are concerned with how to reduce the care responsibilities borne by the family. Leitner (2003) emphasizes the importance of finding ways to unburden the family of its care function. Korpi (2000) measures the type of family support provided by different welfare states, rather than the support given specifically to women. Esping-Andersen (1999) argues that the concept of defamilisation is about reducing households' welfare and care responsibilities. In response to different foci of the defamilisation studies, analysts suggest using different terms to represent different interpretations of defamilisation for example, 'dedomestication' and 'defamilisation'; 'family-based defamilisation' and 'individual-based defamilisation'; and 'economic defamilisation' and 'care-focused defamilisation' (Kroger, 2011; Lohmann and Zagel, 2016; Yu et al., 2017). In view of these suggestions, we use the terms economic defamilisation and care-focused defamilisation to represent two different interpretations of defamilisation - the former stresses women's economic freedom from the family; the latter puts emphasis on family's freedom from care responsibilities. It is reasonable to believe that there is a close connection between a government's attempts to enhance care-focused defamilisation and its attempts to strengthen economic defamilisation. Many care providers in the family are women (International Labour Organisation, 2018; UN Women, 2019). If the government provides some measures such as formal childcare services with the intention of reducing the care responsibilities of the family, it may be able to provide women with the opportunities for choosing not to play the role of the care provider in the family. As a result, women may have more time to earn a living in the paid labour market and achieve a higher degree of financial autonomy in the family. This means that women may also gain more resources to choose not to perform the role of the receiver of financial support in the family.

\section{ADULT WORKER MODEL}

Given significant demographic and societal changes over the past few decades, including a decline in fertility rates and marriage rates and a growing demand for labour flexibility, it is commonly believed that the male-breadwinner model plays a less important role in informing the design of family policies than before (Ciccia and Bleijenbergh, 2014; Johnson, 2019; Lewis, 2001). As a result, there is a growing volume of studies of the adult worker model, which suggests that both men and women should take part in formal employment (Annesley, 2007; Daly, 2011; Larsen, 2005; Lewis and Giullari, 2005; Lewis, et al, 2008). The adult worker model studies are highly related to the EU's Lisbon Strategy agreed in 2000 and re-launched in 2005 (Annesley, 2007). This Strategy explicitly supports the activation of women. For example, it set the target of raising the employment rate of women to $60 \%$ by the year 2010 (European Commission, 2010a). This strategy is supported by the discussion of other international agreements. The Europe 2020 Strategy proposed the target of having $75 \%$ of the population aged 20-64 employed (European Commission, 2010b). The 2030 Agenda for 
Sustainable Development stresses the importance of creating decent and formal employment opportunities for all women and men (United Nations, 2015).

There are a number of studies about how to uphold the adult worker model (Annesley, 2007; Daly, 2011; Lewis and Giullari, 2005; Lewis, 2001; Marceno and Pera, 2017). Most of them focus on the roles played by the government in encouraging people to organise their life based on the adult worker model. It is possible that the government may try to do so by adopting a low intervention approach. By taking as limited action as possible to assist women to become workers, this approach gives people hardly any choice but to take part in the work economy in order to earn a reasonable living (Lewis and Giullari, 2005). An alternative to the low intervention approach is the supported approach. This approach focuses on supporting people (especially women) to reconcile work with care duties (Daly, 2011). This article joins the discussion of the role of the government in promoting the adult worker model. It focuses on two strategies that the government may use to uphold this model - the 'condition-building' and the 'rewarding/penalizing'. The condition-building strategy is indebted to the ideas of the supported approach, whereas the rewarding/penalizing approach is to a certain extent related to the low intervention approach.

The condition-building strategy stresses the importance of creating favourable conditions for women (and men) to take part in formal employment. Examples of this strategy are the provision of formal childcare programmes and vocational training programmes. The former serves to outsource the care responsibilities of the family to other sectors and may be able to give the care providers in the family (usually women) more time to take part in formal employment; the latter may enable women to learn more vocational skills so as to increase their employability. Moreover, the provision of these programmes conveys a message that taking part in formal employment is a social good. That is why the government uses public resources to assist women to participate in formal employment.

The rewarding/penalizing strategy stresses that the allocation of major welfare to the public is based on people's participation in the work economy. This makes those who are willing and able to take part in formal employment the 'deserving group' for social welfare and those who are unwilling or unable to take part in formal employment the 'undeserving group'. Examples of this strategy are some pension reform measures implemented in Europe. Many European countries have been reforming their pension systems following the concept that assumes stable employment in terms of duration and place of work (Frericks et al., 2009; Grady, 2015). They not only increase the pension age but also make a long period of contribution to the pension scheme a qualifying condition for receiving full pension entitlement. These changes convey a message that all people should spend most of the adult life on formal employment. Moreover, for people whose participation in the work economy has frequent interruptions, the chances of receiving sufficient pension incomes to secure a decent retirement are undermined (Ginn and MacIntyre, 2013; Grady, 2015). Trying to avoid this problem may give people the incentive to work longer in the work economy, though the entry into and the exit from the work economy are not necessarily within the control of individual workers but are affected by a number of factors, such as the availability of decent jobs and job protection measures (Cook, 2018; Deeming and Smyth, 2018). 
A government's attempt to support the adult worker model can have mixed implications for women's opportunities to choose not to perform important family roles. If a government implements the condition-building strategy through expanding the provision of formal childcare services, it will provide favourable conditions for women to choose not to perform the role of the care provider in the family. If a number of female care providers in the family choose to use the formal childcare services and use the time saved to earn a living in the paid labour market, economic defamilisation can also be enhanced. This also means that women have the opportunities to choose not to play the role of the receiver of financial support in the family.

If a government implements the rewarding/penalizing strategy by requiring people to make contributions to the pension schemes for a longer period of time before they can be given pension incomes, it will increase the difficulties for women with short and/or fragmented career to achieve financial autonomy in the family after retirement. In this case, it can be said that the rewarding/penalizing strategy can make it difficult for women not to perform the role of the receiver of financial support in the family in their later stage of life.

\section{SEARCHING FOR EMPIRICAL EVIDENCE}

This section is intended to show the empirical significance of the strategies used by governments to promote the adult worker model. Using comparative data allows us to show the relevance of these strategies to a number of countries. Specifically, to fulfil this purpose, we discuss comparative data concerning early childhood education and care (ECEC) and the government's decision on the adjustment to pension age in 14 countries (Austria, Belgium, Denmark, Finland, France, Germany, Hungary, Ireland, the Netherlands, Poland, Portugal, Spain, Sweden, and the UK), and the implications of these data.

The 14 countries were chosen for discussion because they are covered by previous defamilisation studies (Bambra, 2007; Chau et al., 2017; Esping-Andersen, 1999; Kroger, 2011). Also, such selection is constrained by the availability of high-quality comparable data provided by the Organisation for Economic Co-operation and Development (OECD) (2019a, $2019 b, 2020$ ). In order to collect and interpret data, some previous defamilisation studies have developed typologies. The advantage of the typology method is that it can make us more aware of ideal defamilisation patterns. Moreover, we can compare the similarities and differences between the typologies based on the concepts of defamilisation and the typologies based on other welfare concepts such as labour decommodification. However, this method has weaknesses. Analysts point out that the multiplicity and complexity of the policies involved in the typology may render the typologising exercise arbitrary (Saraceno and Keck, 2010). In view of this limitation, we have chosen not to classify the 14 countries into different exclusive groups based on the concept of defamilisation or the adult worker model. Rather, we focus on showing the different degree of importance attached by the 14 countries to two policy measures (ECEC and the government's attempts to adjust the pension age) which have the potential to strengthen the adult worker model, and the implications of these measures for the opportunities 
that women have for choosing not to perform the roles of the care provider and the receiver of financial support in the family. By doing so, we seek to identify empirical examples to illustrate the mixed impact of a government's attempt to strengthen the adult worker model on defamilisation.

\section{Early Childhood Education and Care}

The provision of ECEC is composed of several formal care and education services, such as those provided by day care centres and creches. There are reasons for researchers studying the adult worker model to focus on ECEC. In discussing the need for ECEC, international organisations such as the European Commission (2009) point out that women's engagement in the labour force is linked to the age of their children, and that women's withdrawal from formal employment could be partly explained by a lack of available provision of care for young children. It is commonly believed that if the government is committed to the provision of ECEC, it can be useful in reducing the work-life balance challenges faced by working parents. In relation to this view, the OECD (2017) stresses that affordable and high quality ECEC can contribute to the increase in female labour force participation; and the European Council (2018) emphasizes that ECEC can enhance the potential of women with children to participate in the labour market.

Table 1 provides the information about at what age children are guaranteed by public authorities a publicly subsidised ECEC place. Such a policy is commonly seen as the indicator of a country's commitment to the provision of ECEC. For example, the European Union set the 'Barcelona target' that childcare should be provided for $33 \%$ of children under 3 years old in the European Union zone in 2002 (European Commission, 2014). While all of the 14 countries provide ECEC, there are significant differences in the age at which children have a guaranteed place in ECEC among them. Denmark, (0.5 year old), Finland (0.8 year old), Germany (1 year old), and Sweden (1 year old) guarantee children an ECEC place when they are very young. Austria and the Netherlands guarantee a child an ECEC place only after his/her fifth birthday. Ireland does not guarantee an ECEC place for children; children in Ireland receive compulsory primary education at the age of 6 .

International organisations such as the European Council (2014) stress that ECEC and childcare leave measures are essential parts of the two-pronged approach for supporting employed parents in work-family reconciliation. The council recognizes that childcare leave measures and ECEC carry out different functions. In the words of the European Commission, 'leave policies... enable parents to stay at home to look after their young children' and ECEC services serve to ensure that 'when parents return to work, good quality care and education is available'. Moreover, the European Commission stresses that 'ensuring synergy and continuity between the ECEC and childcare leave measures is very important'. To enhance our understanding of ECEC in relation to the development of the adult worker model, we also provide information about adequately compensated childcare leave (note 1). As shown in Table 2, some countries such as Hungary (2 years), Austria (2 years), Sweden (1.1 years), Germany (1 year) and Poland (1 year) have greater commitment to the provision of adequately compensated childcare leave. Some countries such as the UK (0.1 year), the Netherlands $(0.3$ 
year) and Belgium ( 0.3 year) are much less committed to the provision of adequately compensated childcare leave. Ireland does not provide any adequately compensated childcare leave. This information shows the existence of childcare gap, which refers to the amount of time childcare is not covered by either childcare leave or a guaranteed place in ECEC. The absence of childcare gap means that parents receive strong financial support from the government to look after their young children and to outsource childcare to the formal sector when they need to go to work. This makes it easier for mothers to reduce their financial reliance on other family members and to reduce their responsibilities for taking care of their young children. As shown in Table 2, Denmark, Finland, and Sweden have no childcare gap. Ireland (6 years) has the largest childcare gap among the 14 countries.

\section{Pension Reforms}

Apart from ECEC, it is also important for researchers looking into the adult worker model to study the government's decision to adjust the pension age. As a number of countries have recently been increasing the pension age (Tinios, et al, 2015), these changes imply that it is not uncommon for the government to use the rewarding/penalizing strategy to support the adult worker model. In fact, increasing the pension age conveys a message that people should work for a longer period of time before seeking any support for pension incomes. This message is further reinforced if the government also emphasizes the contribution period as the qualifying condition for receiving full state pension. Analysts are concerned that raising the pension age puts many women in a disadvantaged position (Grady, 2015). Given the fact that female labour force participation rates are generally lower than male ones (Liam, 2012), some women may face a certain period of unemployment before they reach pension age. In this unemployment period, they may need to financially rely on their male family members against their wish.

Table 3 provides the information about the reforms in pension age in the 14 countries. Most of them will increase the pension age in the near future. The newly proposed pension age ranges from 65 to 67 for women in the 14 countries. Most countries aim to make the pension age for women the same as that for men. Some countries (such as France and Belgium) have made a long period of work contributions the qualifying condition for receiving full state pension.

We share the analysts' concern that women would be disadvantaged by the government's decision to raise the pension age. Such concern is well founded by statistics. Table 4 shows that the average male labour force participation rate and female labour force participation rate in the age range (25-54) is 91.7 and 82.9 respectively (note 2 ). Both rates in this age range are higher than those in the age range (55-64). It is also noteworthy that there is a difference in the labour force participation rate between men and women in the age range 25-54 (8.8). This gender difference is even larger in the age range 55-64 (12.4) (note 3). These statistics imply that it is not easy for people especially women to take part in formal employment in their later stage of life. It is possible that labour force participation rates, including those among older women, could significantly increase before a government raises the pension age. However, no sign of such drastic change has been seen so far. It is thus reasonable to believe that the government's attempt to raise the pension age and make the standard pension age for women 
the same as that for men is very likely to affect a lot of women, making them prone to poverty or giving them no choice but to financially rely on their families.

\section{Implications of the Findings}

This section highlights four lessons learnt from the discussion of comparative findings concerning ECEC policies and pension reforms. The first lesson is concerned with the empirical significance of the strategies used by the government to promote the adult worker model. As shown above, all of the 14 countries provide ECEC, but at the same time, most of them raise the pension age. This implies that most of the 14 countries have used both the condition building strategy and the rewarding/penalizing strategy to strengthen the adult worker model.

The second lesson is concerned with the mixed implications of the adult worker model on women's chances of choosing not to perform certain family roles. The male-breadwinner model has long been criticized for giving women limited choice about how to organise their adult life (Grady, 2015; Marceno and Pera, 2017). In societies dominated by this model, women are expected to spend most of their time on providing care in the family rather than taking part in formal employment. Without the chance of earning a living in the labour market, women may have no choice but to financially rely on men. They may, in turn, lack sufficient bargaining power over the allocation of care responsibilities in the family. As an alternative to the malebreadwinner model, upholding the adult worker model may give women more control over their life. Firstly, it recognizes the potential of women, including that of women with children, to take part in formal employment. Secondly, the government may provide measures, such as those aimed at enhancing ECEC, to assist women to take part in the work economy (Giullari and Lewis, 2006). With more financial resources in hand, women may have a greater say about how to organise their life in the family. However, as discussed above, the positive effects of putting the adult worker model into practice on women's welfare should not be overestimated. The rewarding/penalizing strategy for promoting the adult worker model can have a more negative impact on women's chances of receiving social welfare (such as pension incomes) compared with that on men's. In other words, the gender gap in terms of access to social welfare can be widened. This may lead to women's financial reliance on men in the family in their later stage of life, and undermine their ability to bargain over their preferred ways of organising their life in the family.

The third lesson is concerned with the reciprocal relationship between government policies and policy conditions. On the one hand, government policies can play an important role in shaping the underlying political, economic, and social conditions. For example, by outsourcing the care responsibilities from the family to the public sector, the government may be able to give the family care providers (usually women) more time to take part in formal employment. This may, in turn, increase women's participation in the labour force. On the other hand, the impact of government policies on people's life is affected by the underlying political, economic, and social conditions. For example, while the government can set the years of participation in the labour market as the precondition for accessing public pension, the extent to which this policy affects people's life largely depends on men's and women's actual participation in the labour force. Given relatively low female labour force participation, this pension policy will severely undermine women's chances of having sufficient pension incomes in their later life. In fact, 
despite the policy aimed at encouraging formal employment, women's participation in the labour market continues to be affected by a number of political, economic, and social factors, such as the influence of social norms regarding the gender division of labour in the family and the conditions of the labour market (such as the availability of well-paid jobs for women and sex discrimination) (Addati, et al, 2018; Lewis and Giullari, 2005). Moreover, it is noteworthy that there is a time lag between the implementation of the policy and the changes brought by it. In theory, if the government raises the pension age, it may make more people feel the need to stay in formal employment longer; otherwise, people may fail to get sufficient resources to maintain their standard of living. Nevertheless, there is no guarantee that people are able to prolong their work life immediately after the government raises the pension age. In other words, there can be a large time gap between the implementation of the government policy on the pension age and the adjustment that people are able to make. Those who fail to make the adjustment during this time gap become vulnerable to economic difficulties. In order to prevent people from suffering from the time lag, it is prudent for the government to put its policy ideas into practice only after the policy condition becomes favourable. Following this logic, the government should consider raising the pension age after ensuring that both men and women are given ample opportunity to take part in formal employment and to extend their work life.

The fourth lesson is concerned with the importance of using the concept of economic defamilisation to guide the formulation of pension reform measures. Given that the pension reforms with the emphasis on the adult worker model may not necessarily benefit women, it is worth exploring whether it is desirable to develop pension reforms based on alternative concepts, such as economic defamilisation. As mentioned in the introduction, economic defamilisation stresses women's economic freedom from their family. To achieve economic defamilisation, we need to create favourable conditions for encouraging women to take part in formal employment. At the same time, it is equally important to assist women in accessing the state pension scheme. The idea of economic defamilisation can provide justification for the search for alternative pension reform measures, such as lowering the pension age with reference to the female labour force participation rate in each country and significantly increasing the pension credits so as to support women (and men) who choose to take part in the family as care providers.

\section{CONCLUSION}

This article is concerned with the link between the defamilisation debate and the study of the adult worker model. Based on the comparative data concerning ECEC policies and reforms in pension age, it explores the implications of the strategies that can be used by the government to support the adult worker model for defamilisation. Our discussion of the findings has shown that promoting the adult worker model does not necessarily benefit all women. As shown above, even though the government expects women to spend their adult life on the formal employment, there is no guarantee that women are able to do so. And for this reason, we have stressed the importance of searching for alternative concepts, such as economic defamilisation, for guiding pension reforms. 
As the last part of this article, it is necessary to stress that it is not easy to put the idea of economic defamilisation into practice. The government is expected not only to assist women to participate in formal employment but also to provide sufficient welfare for people who choose not to work. Despite the challenges involved in implementing economic defamilisation, it is worth drawing attention to this concept. Firstly, the discussion of this concept makes us more aware of the importance of helping women to achieve financial autonomy in the family in order to challenge gender inequality in the private and public spheres. Secondly, it serves to challenge the view that helping women to take part in the work economy is the only possible way to promote gender equality and/or increase women's freedom from the family.

Future studies can build on our discussion of the implications of the strategies for promoting the adult worker model for economic defamilisation. It is worth exploring how the implementation of the adult worker model affects the life of specific groups, such as single parents, part-time female workers, and women in midlife. For example, we can compare and analyze their experiences of the ways in which the implementation of the condition-building and rewarding/penalizing strategies affects their chances of achieving the degree of economic defamilisation that they prefer.

Table 1 Starting Age for receiving an ECEC place (by legal entitlement/compulsory regulation)

\begin{tabular}{|l|l|}
\hline Country & Starting age \\
\hline Australia & 5 years old \\
\hline Belgium & 2.5 years old \\
\hline Denmark & 0.5 year old \\
\hline Finland & 0.8 year old \\
\hline France & 3 years old \\
\hline Germany & 1 year old \\
\hline Hungary & 3 years old \\
\hline *Ireland & 6 years old \\
\hline Netherlands & 5 years old \\
\hline Poland & 3 years old \\
\hline Portugal & 4 years old \\
\hline Spain & 3 years old \\
\hline Sweden & 1 year old \\
\hline UK & 3 years old \\
\hline Mean & $\mathbf{2 . 9}$ years old \\
\hline
\end{tabular}

Remark: Ireland does not guarantee an ECEC place for children; children in Ireland receive compulsory primary education at the age of 6 .

Source: European Commission, 2019

Table 2 Childcare Leave

\begin{tabular}{|l|c|c|}
\hline Country & $\begin{array}{c}\text { The total length of childcare } \\
\text { leave }\end{array}$ & Childcare gap \\
\hline Australia & 1.2 years & 3.8 years \\
\hline
\end{tabular}




\begin{tabular}{|l|c|c|}
\hline Belgium & 0.3 year & 2.2 years \\
\hline Denmark & 0.5 year & 0 year \\
\hline Finland & 0.9 year & 0 year \\
\hline France & 0.3 year & 2.7 years \\
\hline Germany & 1 year & 0 year \\
\hline Hungary & 2 years & 1 year \\
\hline *Ireland & 0 year & 6 years \\
\hline Netherlands & 0.3 year & 4.7 years \\
\hline Poland & 3 years & 2 years \\
\hline Portugal & 1 year & 3.5 years \\
\hline Spain & 0.4 year & 2.6 years \\
\hline Sweden & 1.1 year & 0 year \\
\hline UK & 0.1 year & 2.9 year \\
\hline Mean & $\mathbf{0 . 8 6}$ year & $\mathbf{2 . 2 4}$ years \\
\hline
\end{tabular}

Source: European Commission, 2019

Table 3: Adjustment in Pension Age and Related Changes

\begin{tabular}{|c|c|c|}
\hline Country & Pension age & Remark \\
\hline Austria & 65 for men and 60 for women & $\begin{array}{l}\text {-The retirement age for women will } \\
\text { increase from } 60 \text { to } 65 \text { between } 2024 \\
\text { and } 2033 \text {. }\end{array}$ \\
\hline Belgium & 65 & $\begin{array}{l}\text {-The pension age will be increased to } 66 \\
\text { in } 2025 \text { and further to } 67 \text { in } 2030 \text {. } \\
\text {-A full public pension benefit requires } \\
45 \text { career years. }\end{array}$ \\
\hline Denmark & 65 & $\begin{array}{l}\text { The pension age will be increased } \\
\text { gradually to } 67 \text { years in the period } \\
2019-22 \text { and to } 68 \text { in } 2030 . \\
\text { A full public old-age pension } \\
\text { requires } 40 \text { years of residence. }\end{array}$ \\
\hline Finland & $\begin{array}{l}\text { - The national old-age } \\
\text { pension is payable from } \\
\text { the age of } 65 \text {. } \\
\text { - Require } 40 \text { years of } \\
\text { residence }\end{array}$ & \\
\hline France & $\begin{array}{l}\text { A full-rate public pension } \\
\text { requires either one of the two } \\
\text { conditions: } \\
\text { a) minimum contributory } \\
\text { record ( } 41.5 \text { years for } \\
\text { people born in } 1957 \text {, who } \\
\text { can retire at the legal age } \\
\text { of } 62 \text { in } 2019) \text { and the } \\
\text { minimum legal pension } \\
\text { age ( } 62 \text { years for people } \\
\text { born in 1957) }\end{array}$ & $\begin{array}{l}\text { The age of the full-rate pension will } \\
\text { be increased from } 65 \text { to } 67 \text {. }\end{array}$ \\
\hline
\end{tabular}




\begin{tabular}{|c|c|c|}
\hline Country & Pension age & Remark \\
\hline & $\begin{array}{l}\text { b) to be aged at least } 67 \text { (for } \\
\text { people born in 1957) }\end{array}$ & \\
\hline Germany & $\begin{array}{l}\text { The regular old-age } \\
\text { pension is payable from } \\
\text { the age of } 65 \text { and } \\
\text { six/seven months }\end{array}$ & $\begin{array}{l}\text {-For those born in } 1964 \text {, the statutory } \\
\text { retirement age will be } 67 \text {. }\end{array}$ \\
\hline Hungary & $\begin{array}{l}\text { The standard retirement age is } \\
63.5 \text {. }\end{array}$ & $\begin{array}{l}\text { - The pension age will be increased to } \\
65 \text { in } 2022 \\
\text { - } 20 \text { years of service is required for } \\
\text { both the earning-related pension and } \\
\text { minimum pension. }\end{array}$ \\
\hline Ireland & $\begin{array}{l}\text { The state pension is payable } \\
\text { from the age of } 66 .\end{array}$ & $\begin{array}{l}\text { - The age will be increased to } 67 \text { in } \\
2021 \text { and } 68 \text { in } 2028 \text {. } \\
\text { - A person is required to have } 40 \\
\text { years of worth or contribution to } \\
\text { receive the full rate. }\end{array}$ \\
\hline Netherlands & $\begin{array}{l}\text { The basic old-age pension is } \\
\text { payable from the age of } 66\end{array}$ & $\begin{array}{l}\text { - The statutory pension age will be } \\
\text { gradually increased to } 67 \text { in } 2021 \text {. } \\
\text { - All residents are eligible for this } \\
\text { benefit. }\end{array}$ \\
\hline Poland & $\begin{array}{l}\text { The pension age is } 65 \text { for men } \\
\text { and } 60 \text { for women. }\end{array}$ & $\begin{array}{l}\text {-The pension age will be increased to } 67 \\
\text { for both sexes. }\end{array}$ \\
\hline Portugal & $\begin{array}{l}\text { The normal age of retirement } \\
\text { with an old age is } 66 \text { years } \\
\text { and } 4 \text { months in } 2018 .\end{array}$ & $\begin{array}{l}\text { The normal age of retirement can be } \\
\text { reduced by four months for each } \\
\text { year of contribution exceeding } 40 \\
\text { years when the beneficiary turns } 65 \\
\text { years old. }\end{array}$ \\
\hline Spain & $\begin{array}{l}\text { The retirement age for a full } \\
\text { pension benefit is } 65 \text { years } \\
\text { and six months. }\end{array}$ & $\begin{array}{l}\text { - If an individual has } 38.5 \text { years of } \\
\text { contribution, retirement with full } \\
\text { pension benefits is available from } \\
\text { the age of } 65 \text {. } \\
\text { The legal retirement age will be } 67 \\
\text { years in } 2027 \text {. }\end{array}$ \\
\hline Sweden & $\begin{array}{l}\text { Eligibility for the guarantee } \\
\text { pension requires three years } \\
\text { of residency and the } \\
\text { guarantee pension benefit is } \\
\text { available from the age of } 65 \text {. }\end{array}$ & $\begin{array}{l}\text { A maximum guarantee pension } \\
\text { benefit requires } 40 \text { years of } \\
\text { residency. }\end{array}$ \\
\hline $\begin{array}{l}\text { United } \\
\text { Kingdom }\end{array}$ & State pension age is 66 & $\begin{array}{l}\text { - The pension age will be increased to } \\
67 \text { between } 2026 \text { and } 2028 \text {. } \\
\text { - } 30 \text { years of National Insurance } \\
\text { Pension contribution is required for } \\
\text { full basic state pension. }\end{array}$ \\
\hline
\end{tabular}

Source: OECD, 2019a.

Table 4 Labour Force Participation Rates in Different Age Groups

\begin{tabular}{|c|c|}
\hline Country & $\begin{array}{c}\text { Labour force participation rates by gender and } \\
\text { age }\end{array}$ \\
\hline
\end{tabular}




\begin{tabular}{|l|c|c|c|c|c|c|}
\hline \multirow{2}{*}{} & \multicolumn{7}{|c|}{ Male } & \multicolumn{3}{c|}{ Female } \\
\cline { 2 - 7 } & \multicolumn{1}{|c|}{$\begin{array}{c}\text { Age } \\
\mathbf{1 5 - 2 4}\end{array}$} & $\begin{array}{c}\text { Age } \\
\mathbf{2 5 - 5 4}\end{array}$ & $\begin{array}{c}\text { Age } \\
\mathbf{5 5 - 6 4}\end{array}$ & $\begin{array}{c}\text { Age } \\
\mathbf{1 5 - 2 4}\end{array}$ & $\begin{array}{c}\text { Age } \\
\mathbf{2 5 - 5 4}\end{array}$ & $\begin{array}{c}\text { Age } \\
\mathbf{5 5 - 6 4}\end{array}$ \\
\hline Austria & 60.3 & 92.4 & 65.6 & 52.5 & 85.7 & 47.4 \\
\hline Belgium & 32.5 & 89.3 & 59.8 & 29.5 & 80.3 & 48.9 \\
\hline Denmark & 60.5 & 90.1 & 78.3 & 61.8 & 82.8 & 69.0 \\
\hline Finland & 56.8 & 90.3 & 70.5 & 53.6 & 84.9 & 72.4 \\
\hline France & 39.8 & 91.9 & 59.4 & 34.0 & 83.1 & 54.6 \\
\hline Germany & 54.2 & 92.7 & 79.4 & 48.4 & 83.3 & 70.0 \\
\hline Hungary & 37.2 & 93.4 & 70.6 & 26.9 & 80.6 & 47.2 \\
\hline Ireland & 48.2 & 90.6 & 72.1 & 45.9 & 76.6 & 55.0 \\
\hline Netherland & 69.7 & 91.5 & 81.0 & 70.3 & 83.3 & 63.1 \\
s & & & & & & \\
\hline Poland & 39.2 & 91.5 & 62.6 & 31.0 & 79.0 & 40.0 \\
\hline Portugal & 36.1 & 92.7 & 70.9 & 32.5 & 88.0 & 58.8 \\
\hline Spain & 39.3 & 91.7 & 69.2 & 34.3 & 82.3 & 54.4 \\
\hline Sweden & 53.6 & 93.6 & 84.2 & 55.9 & 88.7 & 79.0 \\
\hline UK & 61.9 & 92.0 & 73.3 & 60.0 & 81.5 & 63.1 \\
\hline Mean & 49.2 & 91.7 & 71.2 & 45.5 & 82.9 & 58.8 \\
\hline
\end{tabular}

Source: OECD, 2020.

\section{NOTES}

1. The total length of childcare leave takes into account all the different types of leave (maternity, paternity, and parental leave) and is calculated from the child's birth until both parents return to work. Leave is considered to be adequately compensated if parents receive at least $65 \%$ of their previous earnings during this period (European Commission, 2019).

2. The labour force participation rate is calculated as the labour force divided by the total working-age population. The working age population refers to people aged 15-64.

3. Finland is the only country where the female labour force participation rate is higher than the male labour force participation rate in the age group 55-64.

\section{ACKNOWLEDGEMENT}

This paper is partly supported by the General Research Fund under the Hong Kong Research Grants Council (grant number 12604517); and part of the work has received funding from the Marie Skłodowska-Curie Actions under the European Union's Horizon 2020 research and innovation programme under grant agreement No 708305. 


\section{REFERENCES}

Addati, L., Cattaneo, U., Esquivel, V. and Valarino, I. (2018), Care Work and Care Jobs for the Future of Decent Work, International Labour Organisation, Geneva.

Annesley, C. (2007), “Women's political agency and welfare reform: engendering the adult worker model", Parliamentary Affairs, Vol. 60 No. 3, pp. 452-466.

Bambra, C. (2007), "Defamilisation and Welfare State Regimes: A Cluster Analysis", International Journal of Social Welfare, Vol. 16 No. 4, pp. 326-338.

Chau, R. C., Yu, S. W., Foster, L., and Lau, M. K. (2017), "Defamilisation measures and women's labour force participation - a comparative study of twelve countries", Journal of International and Comparative Social Policy, Vol. 33 No. 1, pp. 73-86.

Ciccia, R. and Bleijenbergh, I. (2014), “After the male breadwinner model? Childcare services and the division of labor in European countries", Social Politics, Vol. 21 No. 1, pp. 50-79.

Cook, S. (2018), "Making growth inclusive: Perspectives on the role of social policy in developing economies", Deeming, C. and Smyth, P. (Eds.), Reframing Global Social Policy: Social Investment for Sustainable and Inclusive Growth, Policy Press, Bristol, UK, pp. 77-98.

Daly, M. (2011), "What adult worker model? A critical look at recent social policy reform in Europe from a gender and family perspective”, Social Politics, Vol. 18 No. 1, pp. 1-23.

Deeming, C. and Smyth, P. (2018), Reframing Global Social Policy: Social Investment for Sustainable and Inclusive Growth, Policy Press, Bristol, UK.

England, P. (2005), "Emerging theories of care work", Annual Review of Sociology, Vol. 31, pp. 381-399.

Esping-Andersen, G. (1999), Social Foundations of Postindustrial Economies, Oxford University Press, Oxford. 
European Commission (2010a), "Employment in Europe 2010”, available at: https://ec.europa.eu/employment_social/eie/chap1-5-2_en.html (accessed 20 September 2020)

European Commission (2010b), "Europe 2020: A European strategy for smart, sustainable and inclusive growth", available at: https://ec.europa.eu/eu2020/pdf/COMPLET\%20EN\%20BARROSO\%20\%20\%20007\%2 0-\%20Europe\%202020\%20-\%20EN\%20version.pdf (accessed 20 September 2020).

European Commission (2014), Key Data on Early Childhood Education and Care in Europe, Eurydice and Eurostat Report.

European Commission (2019), Key Data on Early Childhood Education and Care in Europe, Eurydice Report.

Fahlén, S. (2016), "Equality at home-A question of career? Housework, norms, and policies in a European comparative perspective", Demographic Research, Vol. 35 No. 48, pp. 14111440.

Frericks, P., Maier, R., and de Graaf, W. (2009), “Toward a neoliberal Europe? Pension reforms and transformed citizenship", Administration \& Society, Vol. 41 No. 2, pp. 135157.

Ginn, J. and MacIntyre, K. (2013), “UK pension reforms: Is gender still an issue”, Social Policy and Society, Vol. 12 No. 1, pp. 91-103.

Giullari, S. and Lewis, J. (2006), “The adult worker model family, gender equality and care: the search for new policy principles and the possibilities and problems of a capabilities approach", Economy and Society, Vol. 34 No. 1, pp. 76-104.

Grady, J. (2015), "Gendering pensions: Making women visible”, Gender, Work and Organization, Vol. 22 No. 5, pp. 445-458. 
Israel, S. and Spannagel, D. (2018), "Material deprivation in the EU: A multi-level analysis on the influence of decommodification and familization policies", Acta Sociologica, pp. 1-22. Johnson, C. (2019), “Gender: from the male breadwinner to the independent adult worker", Social Democracy and the Crisis of Equality, Springer, Singapore, pp. 57-79.

Korpi, W. (2000), "Faces of inequality: Gender, class and patterns of inequalities in different types of welfare states", Social Politics, Vol. 7, pp. 127-191.

Kroger, T. (2011), "Defamilisation, dedomestication and care policy: Comparing childcare service provisions of welfare states", International Journal of Sociology and Social Policy, Vol. 31 No. 7/8, pp. 424-440.

Larsen, T. P. (2005), “The myth of the adult worker model: new policy discourses in European welfare states", in Taylor-Gooby, P. (ed.), Ideas and Welfare State Reform in Western Europe, Palgrave Macmillan, UK, pp. 54-80.

Leitner, S. (2003), "Varieties of familialism: The caring function of the family in comparative perspective", European Societies, Vol. 5 No. 4, pp. 353-375.

Lewis, J. (2001), “The decline of the male breadwinner model: Implications for work and care”, Social Politics: International Studies in Gender, State and Society, Vol. 8 No. 2, pp. $152-$ 169.

Lewis J. and Giullari, S. (2005), "The adult worker model family, gender equality and care: the search for new policy principles and the possibilities and problems of a capabilities approach”, Economy and Society, Vol. 34 No. 1, pp. 76-104

Lewis, J., Knijn, T., Martin, C. and Ostner, I. (2008), "Patterns of Development in Work/Family Reconciliation Policies for Parents in France, Germany, the Netherlands and the UK in the 2000s", Social Politics, Vol. 15 No. 3, pp. 261-286. 
Lister, R. (1994), “'She has other duties': women, citizenship and social security”, in Baldwin, S., and Falkingham, J. (Eds.), Social Security and Social Change: New Challenges, Hemel Hempstead, Harvester Wheatsheaf, pp. 31-44.

Lister, R. (1997), Citizenship: Feminist perspectives, Palgrave Macmillan, London.

Lohmann, H. and Zagel, H. (2016), "Family Policy in Comparative Perspective: The Concepts and Measurement of Familization and Defamilization", Journal of European Social Policy, Vol. 26 No. 1, pp. 48-65.

Marceno, S. and Pera, A. (2017), "Choice feminism and adult worker model in neoliberal era. Some effects of inclusive policies", Athens Journal of Social Sciences, Vol. 4 No. 2, pp. $175-186$.

McLaughlin, E. and Glendinning, C. (1994), "Paying for care in Europe: Is there a Feminist approach?”, in Hantrais, L. and Mangen, S. (Eds.), Family policy and the welfare of women, University of Loughborough, Loughborough, pp. 52-89.

Nyberg, A. (2002), "Gender, (de)commodification, economic (in)dependence and autonomous households: the case of Sweden", Critical Social Policy, Vol. 22 No. 1, pp. 72-95.

OECD (2019a), "Pension at a glance 2019", available at: http://www.oecd.org/publications/oecd-pensions-at-a-glance-19991363.htm (accessed 20 September 2020)

OECD (2019b), “OECD family database 2019”, available at: http://www.oecd.org/els/family/database.htm (accessed 20 September 2020)

OECD (2020), “OECD employment outlook 2020”, available at: https://www.oecdilibrary.org/employment/oecd-employment-outlook-2020_1686c758-en (accessed 20 September 2020) 
Ollier-Malaterre, A., Valcour, M., Den Dulk, L., and Kossek, E. E. (2013), “Theorizing national context to develop comparative work-life research: A review and research agenda", European Management Journal, Vol. 31 No. 5, pp. 433-447.

Saraceno, C. (2015), “A critical look to the social investment approach from a gender perspective”, Social Politics: International Studies in Gender, State \& Society, Vol. 22 No. 2, pp. 257-269.

Saraceno, C. and Keck, W. (2010), "Can we identify intergenerational policy regimes in Europe?", European Societies, Vol. 12 No. 5, pp. 675-696.

Saxonberg, S. (2013), "From defamilisation to degenderization: Toward a new welfare typology”, Social Policy and Administration, Vol. 47 No. 1, pp. 26-49.

Taylor-Gooby, P. (1996), "The response of government: fragile convergence”, in George, V. and Taylor-Gooby, P. (Eds.), European welfare policy: squaring the welfare circle, Macmillan, London, pp. 199-219.

Tinios, P., Bettio, F., Betti, G. in collaboration with Georgladis, T. (2015), Men, Women and Pension, European Commission.

United Nations (2015), "Promote inclusive and sustainable economic growth, employment and decent work for all", available at: https://www.un.org/sustainabledevelopment/economicgrowth/ (accessed 20 September 2020)

Walker, A. and Maltby, T. (2012), “Active ageing: A strategic policy solution to demographic ageing in the European Union", International Journal of Social Welfare, Vol. 21 No. s1, pp. S117-S130.

Yu, S. W. K., Foster, L., Chau, R. C. M., and Lee, A. M. (2017), “An investigation of defamilization/familization measures to assist women to save pension income and strengthen the adult worker model—The case of Hong Kong", Asian Social Work and Policy Review, Vol. 11 No. 3, pp. 234-243. 


\section{About the authors}

Wai Kam Yu is Associate Professor in the Department of Social Work at the Hong Kong Baptist University. He teaches social work and social policy. His research interests are social exclusion and defamilisation. Wai Kam Yu is the corresponding author and can be contacted at: samyu@ hkbu.edu.hk

Iris Po Yee Lo is a Doctor of Philosophy (PhD) Candidate at the Department of Sociology, the University of Oxford. Her research interests include family, gender, sexuality, and social policy. She has published articles in several journals, including Archives of Sexual Behavior, Fertility and Sterility, Journal of Sociology, and International Journal of Sociology and Social Policy. Email: iris.lo@ sociology.ox.ac.uk

Ruby C M Chau is Associate Professor in Public and Social Policy in the School of Sociology and Social Policy at the University of Nottingham. Her main research interests are women and welfare, comparative welfare policy in East Asia and Europe, global policy responses to ageing and culturally sensitive health and social care. In her recently completed EU funded project, she studied the social investment perspective on work-family reconciliation policies in seven East Asian and European countries (SIPEA, 708305). Her work has been published in various international journals and refereed books. Email: ruby.chau@nottingham.ac.uk. 